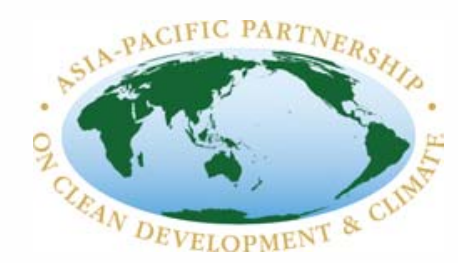

\title{
Country Report on Building Energy Codes in Canada
}

\author{
B Shui \\ M Evans
}

April 2009

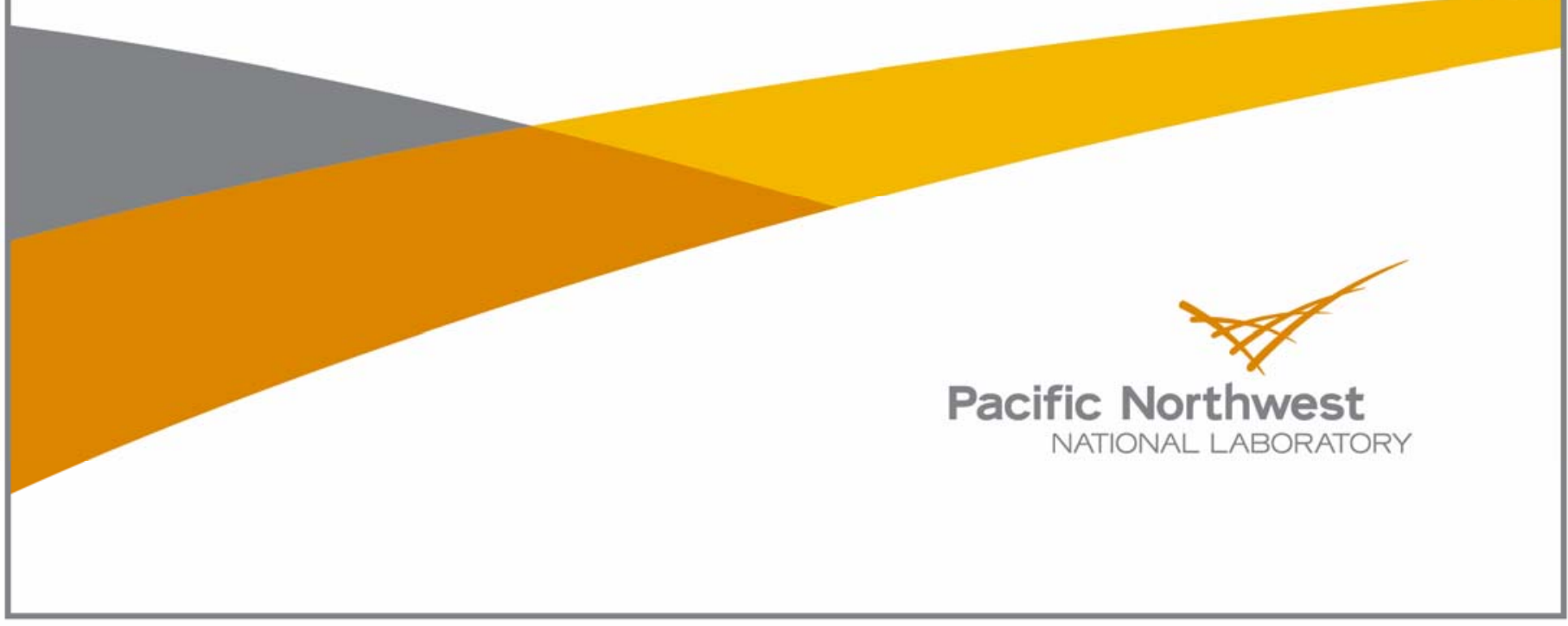




\title{
DISCLAIMER
}

This report was prepared as an account of work sponsored by an agency of the United States Government. Neither the United States Government nor any agency thereof, nor Battelle Memorial Institute, nor any of their employees, makes any warranty, express or implied, or assumes any legal liability or responsibility for the accuracy, completeness, or usefulness of any information, apparatus, product, or process disclosed, or represents that its use would not infringe privately owned rights. Reference herein to any specific commercial product, process, or service by trade name, trademark, manufacturer, or otherwise does not necessarily constitute or imply its endorsement, recommendation, or favoring by the United States Government or any agency thereof, or Battelle Memorial Institute. The views and opinions of authors expressed herein do not necessarily state or reflect those of the United States Government or any agency thereof.

\author{
PACIFIC NORTHWEST NATIONAL LABORATORY \\ operated by \\ BATTELLE \\ for the \\ UNITED STATES DEPARTMENT OF ENERGY \\ under Contract DE-AC05-76RL01830
}

Printed in the United States of America
Available to DOE and DOE contractors from the Office of Scientific and Technical Information,
P.O. Box 62, Oak Ridge, TN 37831-0062;
ph: (865) 576-8401
fax: $(865)$ 576-5728
email: reports@adonis.osti.gov

\begin{abstract}
Available to the public from the National Technical Information Service, U.S. Department of Commerce, 5285 Port Royal Rd., Springfield, VA 22161 ph: (800) 553-6847 fax: $(703) 605-6900$ email: orders@ntis.fedworld.gov online ordering: http://www.ntis.gov/ordering.htm
\end{abstract}

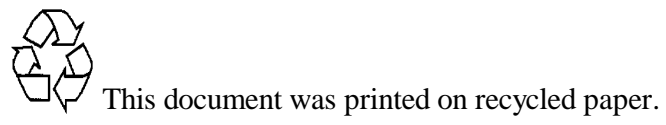


PNNL-18115

\section{Country Report on Building Energy Codes in Canada}

B Shui

M Evans

April 2009 



\section{Foreword}

Buildings account for about $30 \%$ of all energy consumption globally and a significant share of greenhouse gas emissions. Building energy codes help ensure that new buildings use energy efficiently, and this can reduce building energy use by $50 \%$ or more compared to buildings designed without energy efficiency in mind. This is important because buildings typically last 30-50 years, and it is much less expensive and time-consuming to design for energy efficiency than to retrofit a building later. Based on the experience of the Asia-Pacific region, it is clear that building energy codes, when implemented, save energy and improve comfort in new buildings. By design, most building energy codes are cost-effective, saving consumers significant amounts of money on their energy bills.

The Asia-Pacific Partnership on Clean Development and Climate (APP) is a publicprivate collaboration to accelerate the development and deployment of clean energy technologies. APP partners include Australia, Canada, China, India, Japan, Republic of Korea and the United States (the U.S.). APP countries account for more than half of the global economy, energy consumption and greenhouse gas emissions. APP's Buildings and Appliance Task Force (BATF) provides a forum for APP partners to work together on energy efficiency in buildings and appliances. This report was prepared under the framework of BATF, in particular a BATF project called "Survey building energy codes and develop scenarios for reducing energy consumption through energy code enhancement in APP countries" (BATF-06-24).

At the request of the U.S. Department of Energy, the Pacific Northwest National Laboratory's Joint Global Change Research Institute has prepared a series of reports surveying building energy codes in the seven APP countries. These reports include country reports on building energy codes in each APP partner country and a comparative report based on the country reports. This particular report is the country report on building energy codes in Canada. 


\section{Acknowledgements}

This report owes its existence to the Asia-Pacific Partnership on Clean Development and Climate. We would like to thank all the APP partner countries and experts who collaborated on this project. We are particularly grateful to Dr. Seung-Eon Lee at the Korean Institute of Construction Technology for his oversight of the APP project under which this report was prepared (BATF 06-24). We would also like to thank Mark Ginsberg, Jean Boulin and Marc Lafrance from the U.S. Department of Energy for their leadership and financial support of this work.

Diana Shankle, manager of the PNNL Building Energy Codes Program, has provided moral and intellectual support for this project. We appreciate the input and collaboration of the Government of Canada, including input from Robin Sinha, François Dubrous, Jim Clark, Michel Lamanque, Suzanne Deschennes, and their colleagues at Natural Resources Canada. Mark Halverson reviewed this report. Alison Delgado and Kate Williams provided editorial assistance. We would also like to express our gratitude to several other individuals who supported or participated in the APP building energy code assessment in various capacities including Bing Liu, Sriram Somasundaram, Joe Huang, Bipin Shah, Elizabeth Malone, Kay Killingstad, Paulette Land and Kim Swieringa. And we would like to acknowledge the Korean Ministry of Knowledge Economy and the Korea Energy Management Corporation which supported the publication of this report. 


\section{Contents}

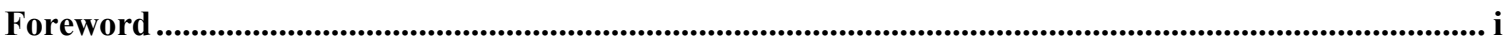

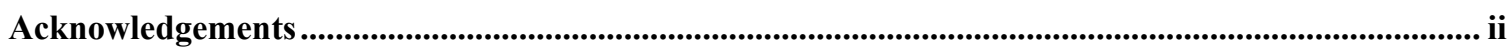

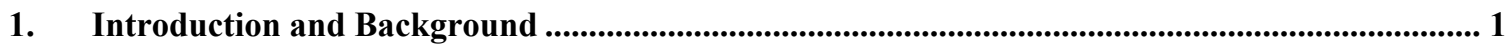

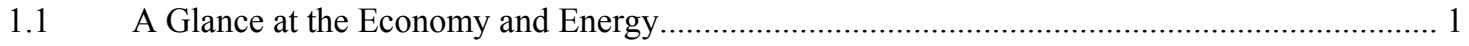

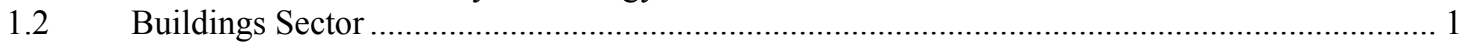

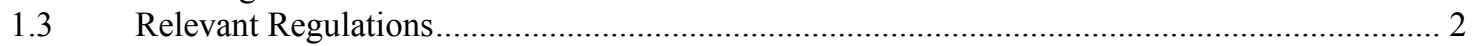

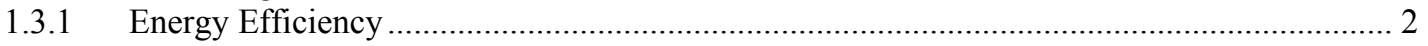

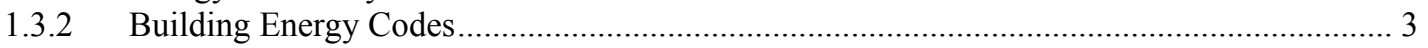

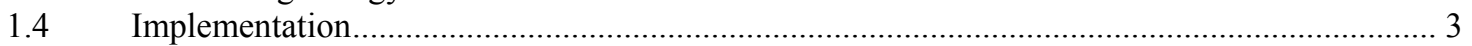

2. The Model National Energy Code for Buildings and Houses (MNECB and MNECH)............... 4

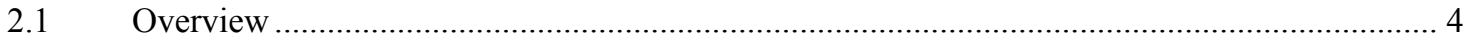

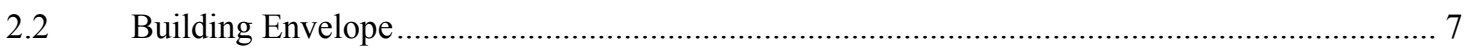

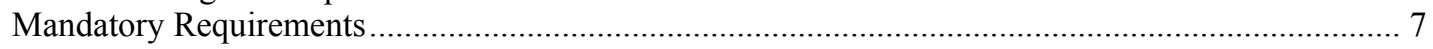

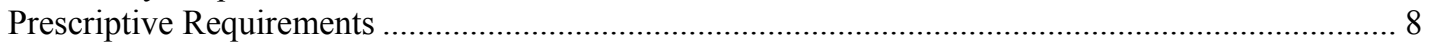

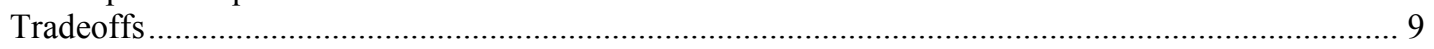

Building Energy Performance Compliance Path ………................................................................ 9

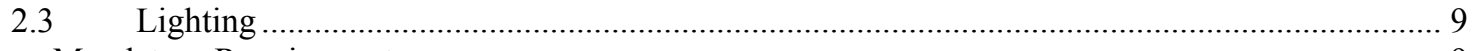

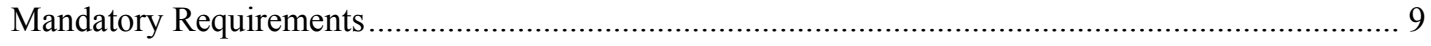

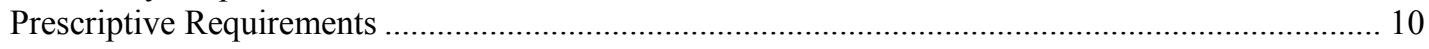

Building Energy Performance Compliance Path ........................................................................... 11

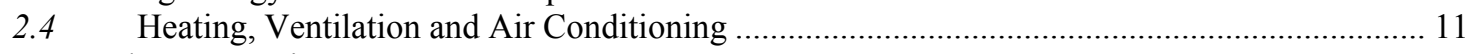

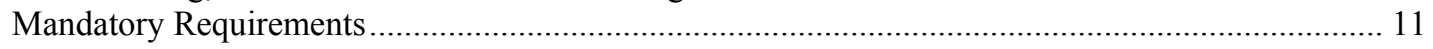

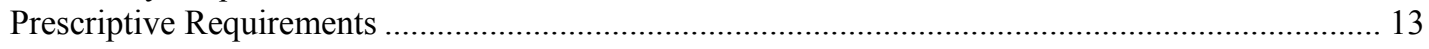

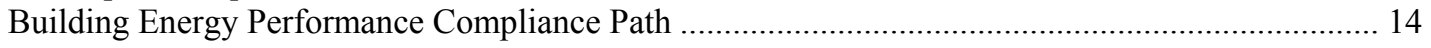

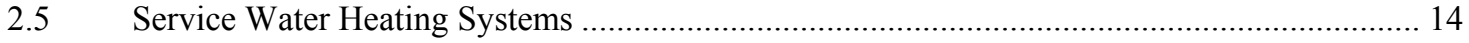

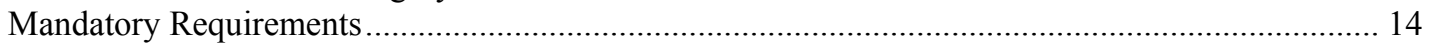

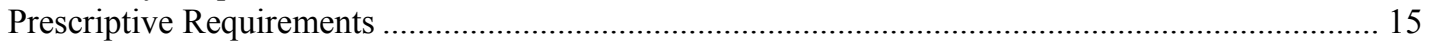

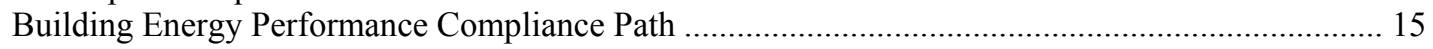

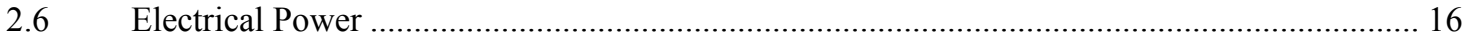

2.7 Building Energy Performance Compliance Path .................................................................... 16

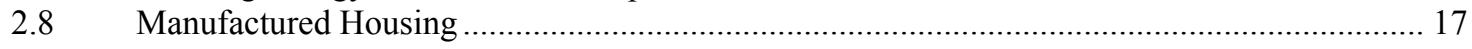

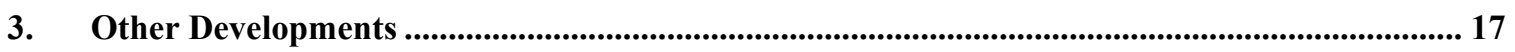

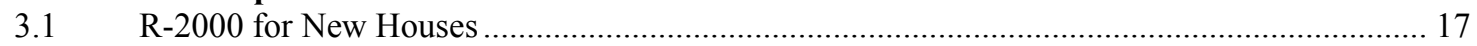

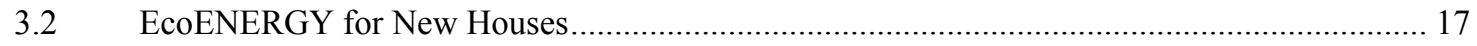

3.3 EcoENERGY for Existing Homes and Incentive Programs ................................................... 18

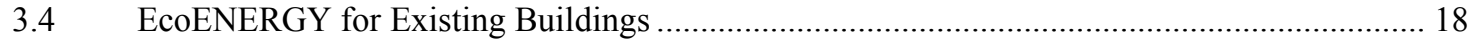

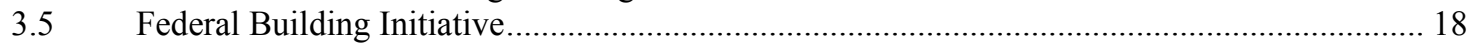

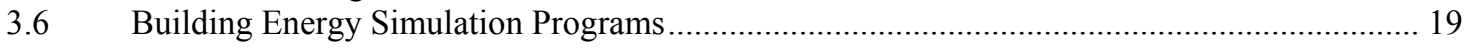

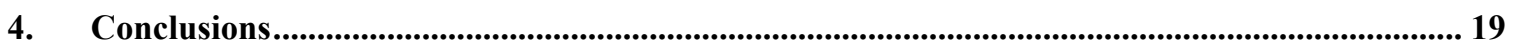

List of Acronyms ................................................................................................................................................. 20

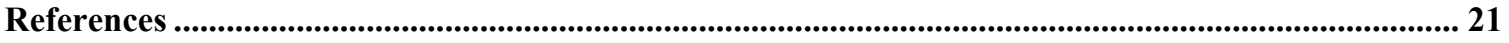

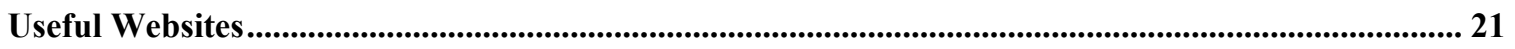




\section{List of Figures}

Figure 1 Energy Consumption by Sector in Canada, 1990-2005 ……................................................... 2

Figure 2 Prescriptive, Tradeoff and Performance Compliance in MNECB and MNECH .......................... 5

\section{List of Tables}

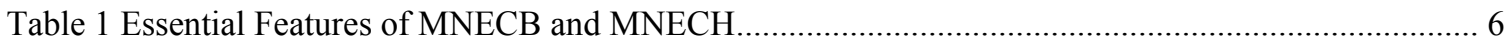




\section{Introduction and Background}

\subsection{A Glance at the Economy and Energy}

In 2007, the gross domestic product (GDP) of Canada was US\$1.3 trillion, and it enjoyed a per capita GDP of US\$26,330 (IMF, 2008). ${ }^{1}$ Canada's economy is fueled by a wealth of domestic natural resources. Canada is the second largest net exporter of natural gas, and it also exports coal and petroleum. In 2005, Canada produced 481 million tons of oil equivalent (Mtoe) of primary energy, and consumed 361 Mtoe. In 2006, Canada emitted 614 millions tons of carbon dioxide (EIA, 2008).

\subsection{Buildings Sector}

Buildings in Canada had a total floor space of 2.2 billion square meters in 2005, 71\% of which was in residential buildings, and the remainder in commercial buildings (OEE, 2007). Most dwellings in Canada are single detached houses (67\% of residential floor space in 2005), followed by apartments (21\%), single attached houses (10\%) and mobile homes $(2 \%)$. There are four major uses of commercial buildings in Canada: offices (35\% of commercial floor space), retail trade (17\%), educational service $(14 \%)$, and health care and social assistance (9\%).

According to International Energy Agency (IEA), the buildings sector is the largest sectoral energy user in Canada (Figure 1). It contributed to nearly one-third of Canada's final energy use ${ }^{2}$ between 1990 and 2005 (IEA, 2007).

Homes and commercial buildings both used about 31 Mtoe of final energy in 2005 (IEA, 2007). The top three end uses in dwellings are space heating $(60 \%$ of the residential energy use in 2005), water heating (18\%) and appliance usage (14\%) (OEE, 2007). Space heating $(51 \%)$, auxiliary equipment $(14 \%)$ and lighting $(9 \%)$ are the three main end uses in commercial buildings (OEE, 2007).

\footnotetext{
${ }^{1}$ Nominal GDP in current U.S. dollars. Canada's GDP based on purchasing power parity was US\$1.2 trillion that year. Its per capita GDP based on purchasing power parity was US\$36,178.

${ }^{2}$ Final energy demand includes consumption of renewable and waste energy.
} 
Figure 1 Energy Consumption by Sector in Canada, 1990-2005

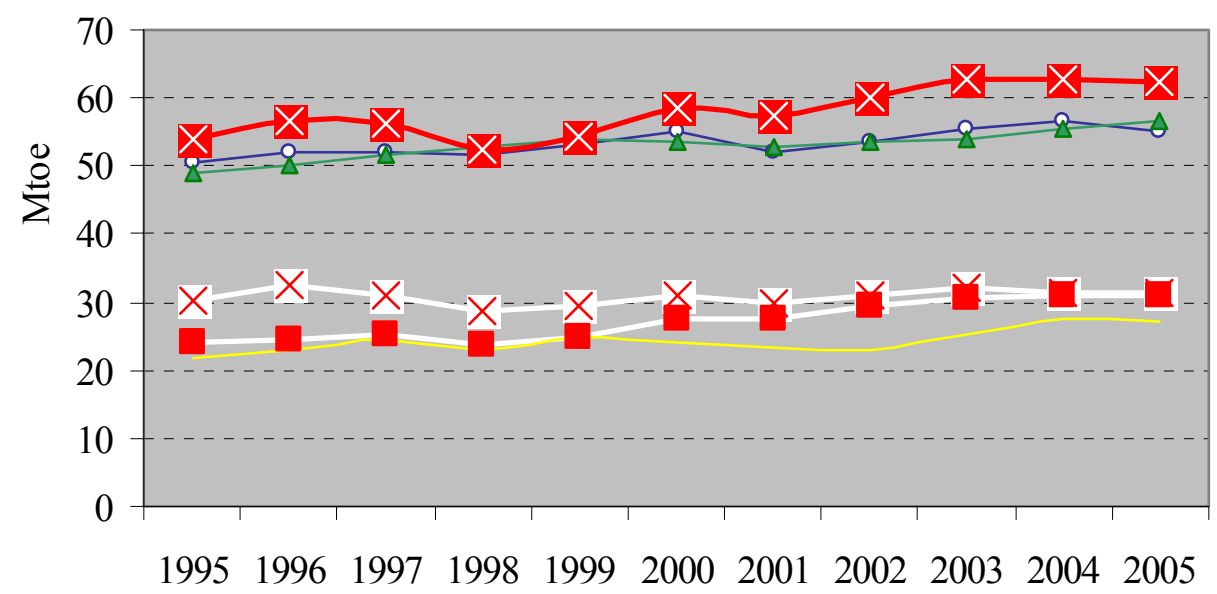

\begin{tabular}{|c|c|}
\hline $\begin{array}{ll} & \text { - Industry Sector } \\
\times & \text { Residential } \\
-\mathrm{X} & \text { Building Sector }\end{array}$ & $\begin{array}{ll}\Delta \quad \text { Transportation } \\
\text { Commerce and Public Services } \\
\text { Others }\end{array}$ \\
\hline
\end{tabular}

Notes: Energy consumption in this figure refers to final energy use, which includes consumption of renewable and waste energy; the sector "Others" includes agriculture, forestry, fishing, and nonspecified and non-energy use.

Source: IEA, 2007

\subsection{Relevant Regulations}

\subsubsection{Energy Efficiency}

Canada approved its first comprehensive law on energy efficiency, the Energy Efficiency Act, in 1992. This act gives the Government of Canada the authority to make and enforce regulations related to performance and labeling requirements for energy-consuming products (as well as doors and windows). The act only applies to products that are imported or shipped between provinces. The act also gives the Government of Canada the authority to collect statistics on energy use and alternative energy (OEE, 2006, 2009).

The first Energy Efficiency Regulations under the Energy Efficiency Act came into force in 1995. Regulations have been established for more than 30 products, including heating and cooling equipment, water heaters and lighting. Amendments to the Energy Efficiency Regulations have raised the efficiency standards in the residential, commercial and institutional sectors (OEE, 2009).

Natural Resources Canada (NRCan) is the main department of the Canadian government responsible for natural resources and energy. It has promoted energy efficiency and the use of alternative energy since the late 1970s. NRCan's policy instruments include: regulation, financial incentives, leadership, information, voluntary initiatives, research and development funding, and technology demonstrations (OEE, 2006, 2009). The Office of Energy Efficiency (OEE) of NRCan, established in 1998, undertakes market transformation initiatives to improve energy efficiency. OEE has initiated many influential projects and policies to promote building energy efficiency. 


\subsubsection{Building Energy Codes}

Canada has seven national building $\operatorname{codes}^{3}$, and two of them are related to building energy efficiency: the Model National Energy Code of Canada for Buildings (MNECB) and the Model National Energy Code for Houses (MNECH). The Canadian Commission on Building and Fire Codes (CCBFC), funded by code sales and the National Research Council (NRC), is responsible for developing and updating six of the model national codes.

The CCBFC prepared both MNECB and MNECH, and NRC first published them in 1997. Hereafter, this report uses the terms MNECB and MNECH to refer to the 1997 versions of the two national model energy codes. NRC, NRCan, the Canadian Electricity Association, and the provincial and territorial ministries of energy funded the research to develop the model code and the supporting software. MNECB and MNECH were heavily influenced by ASHRAE 90.1-1989.

In April 2008, NRC and NRCan announced that they were joining forces to update MNECB. NRCan is providing technical expertise and up to $\$ 5$ million to support this initiative.

NRC will publish the new energy code in 2011 . The new code will complement the next version of the model national construction codes, which are scheduled for publication in 2010 (NRC, 2008).

\subsection{Implementation}

Under Canada's Constitution Act, building regulation is the responsibility of provincial and territorial governments. Thus, the appropriate provincial and local authorities must adopt MNECB and MNECH for them to take effect. To date, the Province of Ontario and the City of Vancouver have referenced MNECB in their building regulations and enforced its requirements. No other province or territory has adopted MNECH in its entirety, although a few have used some of its requirements in their building codes (NRC, 2006, 2007).

The provinces and territories each devise their own programs to implement the building codes. However, these programs typically include:

- Design reviews,

- Inspections at several stages during construction,

- Penalties for non-compliance, including withholding construction and occupancy permits and charging fines,

- Training for building inspectors and other stakeholders, and

- Licensing of building trade workers and professionals.

\footnotetext{
${ }^{3}$ The other building codes are the (1) National Building Code of Canada (NBC), (2) National Fire Code of Canada, (3) National Plumbing Code of Canada, (4) National Farm Building Code, and (5) National Housing Code and Illustrated Guide.
} 
In most cases, building codes are in the jurisdiction of the provinces. In some provinces in the East, in particular, Newfoundland, Labrador and Prince Edward Island, the provincial governments have left jurisdiction on building codes up to city and town governments. Implementation programs may not be as extensive in small towns as they are in large towns or provinces (and some towns may opt not to adopt building codes) (Nationalcodes.ca, 2002).

The Canadian Code Centre, which is part of NRC, also has staff that train and advise building officials, designers and other code officials.

MNECB and MNECH specify that any compliance software used must comply with "Performance Compliance for Buildings: Specifications for Calculation Procedures for Demonstrating Compliance to the Model National Energy Code for Buildings Using Whole Building Performance" or "Performance Compliance for Houses: Specifications for Calculation Procedures for Demonstrating Compliance to the Model National Energy Code for Buildings Using Whole Building Performance"(CCBFC, 1999a, b) .

Canada also has a clear system of testing building materials. The Canadian Standards Organization, Underwriters' Laboratories of Canada and other organizations test and certify products against regulatory standards. The code does not require such certification, but building code officials often rely on this certification to ensure that components, like windows, meet the minimum standards (Nationalcodes.ca, 2002).

Currently, provincial and territorial governments, and industry associations employ other regulatory and non-regulatory standards to design energy-efficient buildings, and the standards may differ by province. The code description below highlights the provisions that are currently regulated by local governments. The purpose of the updated model energy code would be to improve energy efficiency in new buildings while providing Canada's construction sector with a single set of minimum requirements for energy efficiency in buildings (NRC, 2008). The hope and plan is that by developing this code with the participation of all the provinces and territories, these local governments will all adopt the new code (Nationalcodes.ca, 2002).

\section{The Model National Energy Code for Buildings and Houses (MNECB and MNECH)}

\subsection{Overview}

NRC released the first and only national model energy codes in 1997. MNECB and MNECH are designed to conform with the relevant provincial, territorial or municipal regulations, or in the absence of such regulations, to conform with the National Building Code of Canada, or NBC. They do this by referring to the requirements in these other regulations in many specific provisions. 
MNECB and MNECH contain cost-effective minimum requirements for energy efficiency in new buildings and housing, respectively. MNECB applies to all buildings ${ }^{4}$, other than single family houses of three stories or less, and to additions of more than ten square meters to such buildings. MNECH applies to single family houses of three stories or less, and to additions of more than ten square meters (NRC, 2006, 2007). MNECH also has a section on manufactured housing.

To allow flexibility in achieving the minimum required level of energy efficiency, both MNECB and MNECH offer three compliance approaches: a prescriptive path, a tradeoff path (covering the building envelope only) and a performance path (Figure 2 ). The performance path is an alternative to the prescriptive requirements. The tradeoff path for the building envelope can involve either simple tradeoffs or tradeoffs designed with computer simulation.

Figure 2 Prescriptive, Tradeoff and Performance Compliance in MNECB and MNECH

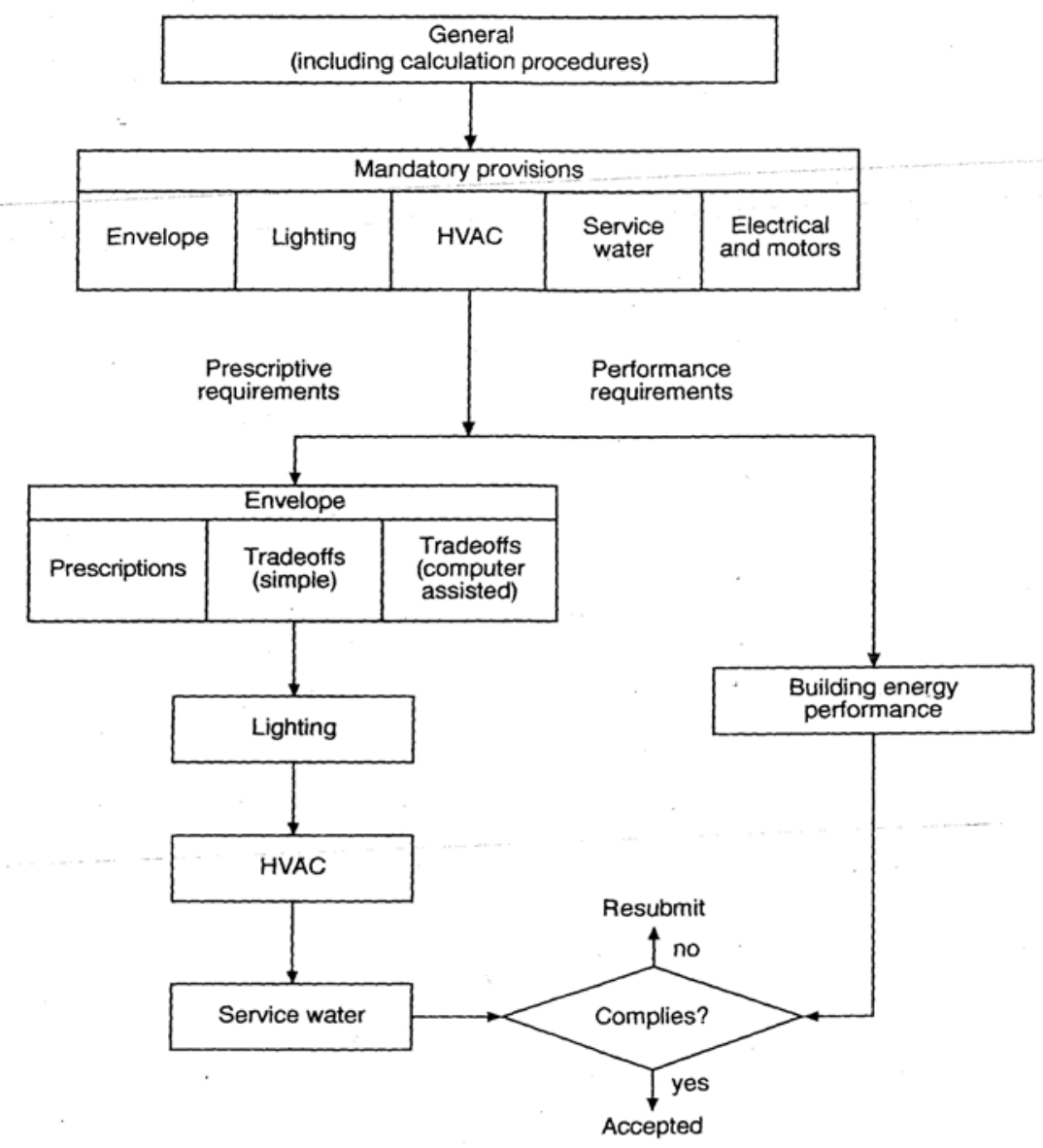

Source: $M N E C B 1997$

\footnotetext{
${ }^{4}$ MNECB does not apply to farm buildings, unheated buildings, greenhouses or buildings with transient occupancy.
} 
MNECB has eight parts with seven appendixes. MNECH is also divided into those same eight parts, and it has a Part 9 on Manufacturing Housing (Table 1).

Table 1 Essential Features of MNECB and MNECH

\begin{tabular}{|c|c|c|}
\hline $\begin{array}{l}\text { Part Number and } \\
\text { Title for MNECB } \\
\text { (Buildings) }\end{array}$ & $\begin{array}{l}\text { Part Number and } \\
\text { Title for MNECH } \\
\text { (Houses) }\end{array}$ & Descriptions \\
\hline \multicolumn{2}{|c|}{ Part 1 Scope and Definitions } & $\begin{array}{l}\text { The buildings and parameters covered by this code, the definitions of } \\
\text { all terms that have a constrained or specific meaning in this code, as } \\
\text { well as a list of abbreviations used in this code }\end{array}$ \\
\hline \multicolumn{2}{|c|}{ Part 2 General Requirements } & $\begin{array}{l}\text { Provisions of an administrative nature such as compliance, } \\
\text { calculation methods, climatic data, documentation, referenced } \\
\text { documents, provisions for equivalent materials, systems, equipment, } \\
\text { and the construction review process }\end{array}$ \\
\hline \multicolumn{2}{|c|}{ Part 3 Building Envelope } & $\begin{array}{l}\text { Requirements related to the thermal resistance and air tightness of the } \\
\text { various building components that make up the building envelope }\end{array}$ \\
\hline \multicolumn{2}{|l|}{ Part 4 Lighting } & $\begin{array}{l}\text { Requirements intended to minimize energy use for lighting and to } \\
\text { encourage efficient lighting controls }\end{array}$ \\
\hline \multicolumn{2}{|c|}{$\begin{array}{l}\text { Part } 5 \text { Heating, Ventilating and Air- } \\
\text { conditioning Systems }\end{array}$} & $\begin{array}{l}\text { Requirements for the design and installation of heating, ventilating } \\
\text { and air-conditioning systems with the characteristics and controls } \\
\text { necessary to operate efficiently }\end{array}$ \\
\hline \multicolumn{2}{|c|}{ Part 6 Service Water Heating Systems } & $\begin{array}{l}\text { Requirements for the design and installation of service water heating } \\
\text { systems with the characteristics and controls necessary to operate } \\
\text { efficiently }\end{array}$ \\
\hline \multicolumn{2}{|c|}{ Part 7 Electrical Power } & $\begin{array}{l}\text { Requirements for those electricity-consuming features of buildings } \\
\text { not covered in Parts } 4,5 \text { and } 6\end{array}$ \\
\hline \multicolumn{2}{|c|}{$\begin{array}{l}\text { Part } 8 \text { Building Energy Performance } \\
\text { Compliance }\end{array}$} & $\begin{array}{l}\text { An alternative approach to the prescriptive requirements of other } \\
\text { parts by specifying a means of demonstrating that a building will not } \\
\text { use more energy than if it were to comply with those prescriptive } \\
\text { requirements }\end{array}$ \\
\hline Not Applicable & $\begin{array}{l}\text { Part } 9 \\
\text { Manufactured } \\
\text { Housing }\end{array}$ & $\begin{array}{l}\text { Specific requirements and exemptions from certain requirements of } \\
\text { the code for manufactured housing }\end{array}$ \\
\hline \multicolumn{2}{|c|}{ Appendix A Regional Requirements } & $\begin{array}{l}\text { Tables of regional requirements for the thermal characteristics of the } \\
\text { envelope, heat recovery and energy source adjustment factors }\end{array}$ \\
\hline \multicolumn{2}{|c|}{$\begin{array}{l}\text { Appendix B Thermal Characteristics } \\
\text { of Common Building Components }\end{array}$} & $\begin{array}{l}\text { Tables of thermal characteristics of common building components, } \\
\text { such as exterior walls, windows, doors, roofs, exposed floors, } \\
\text { foundation walls and floors on ground }\end{array}$ \\
\hline \multicolumn{2}{|c|}{$\begin{array}{l}\text { Appendix C Method for Calculating } \\
\text { the Thermal Properties of Building } \\
\text { Components }\end{array}$} & $\begin{array}{l}\text { Methods required in Part } 2 \text { for establishing the overall thermal } \\
\text { transmittance of building components for the purpose of checking } \\
\text { compliance with the requirements of this code }\end{array}$ \\
\hline \multicolumn{2}{|c|}{$\begin{array}{l}\text { Appendix D Energy Source } \\
\text { Adjustment Factors }\end{array}$} & $\begin{array}{l}\text { A table of regional energy source adjustment factors used in } \\
\text { determining the principal heating source of a building and used by the } \\
\text { computer-assisted tradeoff software and the performance compliance } \\
\text { software }\end{array}$ \\
\hline \multicolumn{2}{|c|}{ Appendix E Commentary } & $\begin{array}{l}\text { Additional explanatory information to assist code users in } \\
\text { understanding the intent of the requirements contained in Parts } 1 \text { to } 8\end{array}$ \\
\hline \multicolumn{2}{|c|}{$\begin{array}{l}\text { Appendix F Determination of } \\
\text { Regionally Sensitive Requirements }\end{array}$} & $\begin{array}{l}\text { The calculation method used to establish the levels of the regional } \\
\text { requirements of the code and details of the parameters considered }\end{array}$ \\
\hline \multicolumn{2}{|c|}{ Appendix G Convention Factors } & $\begin{array}{l}\text { A table of factors for converting units used in this code from the } \\
\text { metric system to the imperial system }\end{array}$ \\
\hline
\end{tabular}

Sources: MNECB 1997 and MNECH 1997 


\subsection{Building Envelope ${ }^{5}$}

The building envelope must comply with both the mandatory provisions ${ }^{6}$. It must also comply with the prescriptive criteria unless it complies with the code through the tradeoffs or building energy performance method. These provisions apply to buildings and houses with conditioned space.

\section{Mandatory Requirements ${ }^{7}$}

Both MNECB and MNECH require that "components of the building envelope shall be in accordance with provincial, territorial or municipal building regulations, or, in the absence of such regulations, with the National Building Code of Canada." In addition, the section provides requirements on continuous insulation barriers and the methodology to calculate overall thermal transmittance of components ${ }^{8}$.

Besides the general mandatory requirements above, the mandatory envelope requirements also cover (1) above-ground components of the building envelope, (2) building components in contact with the ground and (3) air tightness. The numbered bullets below summarize the mandatory requirements for the building envelope in MNECB, along with a brief comparison to the corresponding subsections in $\mathrm{MNECH}$ :

(1) MNECB and MNECH provide mandatory requirements for roofs (such as roof components, ceiling components and the sloped attic-type roofs) and walls. $\mathrm{MNECH}$ also lists the requirements for vestibules.

(2) MNECB provides mandatory regional minimum effective thermal resistance values (R-values ${ }^{9}$ ) for roofs, walls and floors and other components by heating source. In addition, it states mandatory requirements (such as insulation) for roofs, walls and floors. MNECH only breaks out mandatory R-values by principal heating source for walls.

(3) Both MNECB and MNECH require that walls, doors and other air barriers be built in accordance with the provincial, territorial or municipal building regulations or, in the absence of these regulations, in accordance with applicable requirements of the NBC. There are also specific provisions for fireplaces, attic doors and garage doors.

\footnotetext{
${ }^{5}$ See Part 3 of both MNECB and MNECH.

${ }^{6}$ Certain exceptions apply. For example, in retrofits of historic buildings where insulation or air sealing may inhibit moisture release, the insulation requirement is waived. Another example is in certain parts of Canada, buildings constructed on certain clay soils are exempt from the foundation insulation requirements to avoid adfreezing (soil freezing to foundation wall or slab causing frost heaving of the structure).

${ }^{7}$ See Section 3.2 of both MNECB and MNECH.

${ }^{8}$ Both MNECB and MNECH employ the term "assemblies". In this country report, the term "components" is used instead for consistency with the terminology in the other country reports in this series.

${ }^{9}$ MNECB and MNECH use the term "RSI", which means R-value in international standard units. For consistency with the other country reports, we use the term R-value.
} 


\section{Prescriptive Requirements $^{10}$}

The prescriptive requirements for the building envelope in MNECB cover $\left(1^{*}\right)$ the aboveground components of the building envelope and (2) special interior temperature conditions. MNECH does not cover special interior temperature conditions, but it does cover building components in contact with the ground.

The first section includes $\left(1.1^{*}\right)$ opaque components ${ }^{11},\left(1.2^{*}\right)$ fenestration (windows and doors), (1.3) certain types of doors and access hatches, and $\left(1.4^{* *}\right)$ unconditioned spaces. Note that an asterisk (*) indicates that MNECB and MNECH have subsections with the same title and similar provisions. The mark "**" indicates that MNECB and MNECH have subsections with the same title and provisions. No asterisk indicates that there is no corresponding subsection in $\mathrm{MNECH}$.

(1.1) For opaque components, the code provides prescriptive requirements of regional maximum overall thermal transmittance (U-value) for above-ground opaque components (including roofs, walls and floors) for different principle heating sources (such as natural gas, electricity, oil, propane, or heat pumps). The code also prescribes specifications on thermal characteristics of other above ground opaque components (such as foundation or solid masonry walls). MNECH provides values for regional minimum effective thermal resistance (R-values) for roofs, walls and floors by principle heating source.

(1.2) For fenestration, the code provides regional maximum thermal transmittance values by heating source, with defined exceptions such as automatic sliding glass doors. MNECB varies the regional maximum thermal transmittance values by the ratio of fenestration to wall area for fixed and operable fenestration products. Where the skylight-to-roof-ratio does not exceed $2 \%$, skylights need not comply with the required values. MNECH has similar requirements.

(1.3) With defined exceptions, overall thermal transmittance for swing doors should range from 2.1 to $2.7 \mathrm{watts} / \mathrm{m}^{2} \cdot{ }^{\circ} \mathrm{C}$, which covers a range from doors with no windows to glass doors. MNECH does not have such provisions.

(1.4) Both codes consider an unconditioned enclosure (such as a sun porch) to provide a thermal resistance of $0.6 \mathrm{~m}^{2} \cdot{ }^{\circ} \mathrm{C} /$ watt, or the equivalent of one layer of glass.

(1.5) MNECB provides different thermal transmittance values for envelope components if those components contains embedded heating or cooling cables, ducts, or pipes.

\footnotetext{
${ }^{10}$ See Section 3.3 of both MNECB and MNECH.

${ }^{11}$ Opaque components means those components of the building envelope that are not transparent. In other words, it includes walls and solid doors but not windows.
} 
In addition, $\mathrm{MNECH}$ provides specifications for building components in contact with the ground (such as walls and floors).

\section{Tradeoffs $^{12}$}

Both MNECB and MNECH have the same interpretation of and requirements for tradeoffs. There are two tradeoff paths: simple tradeoffs and computer-assisted tradeoffs. Simple tradeoffs refer to trading enhanced energy efficiency in one or more above ground components of the building envelope against decreased energy efficiency in one or more other components. With simple tradeoffs, the sum of the energy use of the building envelope should be equal or less than the total required if each individual component were to comply. Building designers may use computer-assisted tradeoff calculations where all walls and windows of the building are vertical and the total area of skylights is no greater than $2 \%$ of the total roof area.

For the tradeoff calculations, MNECH provides specific requirements regarding log walls as well as calculation equations for the effective thermal resistance of doors and windows.

Both codes also discuss restrictions on tradeoffs.

\section{Building Energy Performance Compliance Path ${ }^{13}$}

As an alternative to the prescriptive requirements and tradeoff options for building envelopes, the designer can use the building energy performance compliance path to demonstrate that the building will not use more energy than it would have with the prescriptive requirements.

MNECB and MNECH have the same provisions for building energy performance compliance.

\subsection{Lighting $^{14}$}

MNECB provides mandatory provisions for lighting as well as a choice between the prescriptive path to compliance and the performance-based path. $\mathrm{MNECH}$, on the other hand, only has mandatory provisions for lighting. In both cases, lighting includes lighting in interior spaces, lighting of building exteriors and exterior building areas, and lighting for grounds, parking and other exterior areas associated with building sites.

\section{Mandatory Requirements ${ }^{15}$}

The mandatory requirements for lighting in MNECB cover $\left(1^{*}\right)$ exterior lighting power, $\left(2^{*}\right)$ exterior lighting controls, $\left(3^{*}\right)$ interior lighting power, $\left(4^{*}\right)$ interior lighting controls,

\footnotetext{
${ }^{12}$ See Section 3.4 of both MNECB and MNECH.

${ }^{13}$ See Section 3.5 of both MNECB and MNECH.

${ }^{14}$ See Part 4 of both MNECB and MNECH.

${ }^{15}$ See Section 4.2 of both MNECB and MNECH.
} 
$\left(5^{* *}\right)$ ballasts ${ }^{16}$ and (6) documentation. MNECH covers the first five subsections above. The numbered bullets below summarize the mandatory requirements for lighting in MNECB and provide a brief comparison to the relevant subsections in MNECH:

(1) With a few exceptions, external lamps should generally have an initial luminous efficacy ${ }^{17}$ of no less than 60 lumens/watt. The requirement is less stringent in MNECH: 40 lumens/watt. Entrance and exit lighting should also meet required unit power allowances. The connected lighting power for façade lighting should not be greater than 2.4 watts $/ \mathrm{m}^{2}$ of the façade surface area, which is the same in both MNECB and MNECH.

(2) Exterior lighting should be controlled by lighting schedule controls, photocells or both, with some exceptions. All lighting schedule controls must have backup power in case of outages. MNECH requires that lighting schedule controls be automatic or programmable.

(3) Regarding interior lighting power, exit signs should not demand more than 22 watts of power. This subsection also provides requirements on lighting within residential units. MNECH has the same provisions, plus a subsection on interior lighting power for common areas.

(4) All interior lighting systems must have manual, automatic or programmable controls, with a few exceptions. There should be at least one control on each circuit. MNECB also requires controls to permit lower lighting levels at night for office spaces. This subsection also provides mandatory requirements on the location of controls. Since MNECH is for houses, it does not have the provisions on office night lighting.

(5) MNECB and MNECH have identical mandatory provisions for ballasts, which require that fluorescent lamp ballasts comply with the relevant federal, provincial or territorial standards or the equipment energy-efficiency act, as well as the national test standard CAN/CSA-C654-M, "Fluorescent Lamp Ballast Efficacy Measurements."

(6) MNECB specifies the documentation requirements for compliance. MNECH does not have this provision.

\section{Prescriptive Requirements ${ }^{18}$}

The prescriptive requirements for lighting in MNECB include formulas to calculate interior connected lighting power and the interior lighting power allowance by building

\footnotetext{
${ }^{16}$ A lighting ballast is an electrical component used with a fluorescent bulb and certain other types of lamps to conduct electricity at each end of the tube. It supplies and regulates the amount of electricity that flows through the tube.

${ }^{17}$ Luminous efficacy is the ratio of luminous flux (in lumens) to power (in watts).

${ }^{18}$ See Section 4.3 of MNECB.
} 
type and space function. The calculation methods cover how to determine the area and lighting power density by space function, and how to handle special spaces and activities.

MNECH does not have corresponding prescriptive requirements.

\section{Building Energy Performance Compliance Path ${ }^{19}$}

As an alternative to the prescriptive requirements, buildings can comply with the code through the building energy performance compliance path. To do so, the building designer must demonstrate that the building will not use more energy than it would have if the lighting system complied with the prescriptive lighting requirements. Part 8 of MNECB outlines the procedures for this compliance path. MNECH does not have such provisions.

\subsection{Heating, Ventilation and Air Conditioning ${ }^{20}$}

All heating, ventilation and air conditioning (HVAC) equipment and systems in buildings and houses must comply with the mandatory provisions, and either the prescriptive criteria or building energy performance compliance requirements of MNECB and MNECH.

\section{Mandatory Requirements ${ }^{21}$}

Buildings must have HVAC systems sized to meet the needs of the conditioned spaces where they will operate, in accordance with the relevant provisions of provincial, territorial or municipal regulations, or, in the absence of such regulations, with the National Plumbing Code of Canada.

The mandatory requirements of MNECB also cover $\left(1^{*}\right)$ air distribution systems, $\left(2^{*}\right)$ air intake and outlet dampers, $\left(3^{*}\right)$ piping for heating and cooling systems, (4) pumping system design, $\left(5^{* *}\right)$ equipment installed outdoors, $\left(6^{* *}\right)$ electric heating systems, $\left(7^{*}\right)$ recessed heaters, (8) air distribution systems serving spaces with special requirements, $(9 *)$ temperature controls, $\left(10^{* *}\right)$ humidification, (11) shutoff and set back controls, (12*) equipment efficiency, and (13) documentation. The list below summarizes the mandatory HVAC requirements in MNECB, and provides a brief comparison to the corresponding subsections in MNECH:

(1) Ducts should be designed and installed in accordance with the relevant provincial, territorial or municipal building regulations, or, in the absence of such regulations, with the NBC. Buildings should have air distribution systems, which can be balanced. Ducts and plenums should be sealed and insulated according to the equipment specifications. MNECB provides an equation to test duct leakage. Duct insulation should be protected under certain circumstances. MNECH has similar but much less comprehensive provisions regarding air distribution systems.

\footnotetext{
${ }^{19}$ See Section 4.4 of MNECB.

${ }^{20}$ See Part 5 of MNECB and MNECH.

${ }^{21}$ See Section 5.2 of both MNECB and MNECH.
} 
(2) Every duct or opening for air discharge from a conditioned space must have a motorized damper unless the duct serves a continually operating system or the duct opening is small (less than $0.08 \mathrm{~m}^{2}$ in opening area). MNECB has specific requirements about the type and location of dampers. MNECH has similar but less comprehensive provisions.

(3) Piping should be designed and installed in accordance with the relevant provincial, territorial or municipal building regulations, or, in the absence of such regulations, with the NBC. Designs should ensure that piping can be balanced. Insulation and condensation protection are also mandatory on piping. MNECB piping insulation requirement is tabulated according to pipe diameter and the temperature of the pipe fluid (heating/cooling). $\mathrm{MNECH}$ has similar but less comprehensive provisions regarding piping.

(4) The subsection on piping system design applies to all HVAC pumping systems with a total pump system motor power of $7.5 \mathrm{~kW}$ or greater. There is no such provision in MNECH.

(5) Equipment installed outdoors or in unconditioned spaces must be designed by the manufacturer for such installation. MNECH has the same provision.

(6) Remotely mounted thermostats must control electric baseboard heaters. $\mathrm{MNECH}$ has the same provision.

(7) Recessed heaters that partly penetrate the building envelope must be located on the warm side of the insulation and should not increase the overall thermal transmittance at the project area of the heater to more than the permitted values (MNECB). In addition, the recessed heaters should not reduce the effective thermal resistance at the project area of the heater to more than the permitted values for houses (MNECH).

(8) Separate air distribution systems generally must serve spaces with special requirements for process temperature, humidity or both. MNECH does not have such requirements.

(9) MNECB and MNECH have similar subsections covering the temperature range of thermostatic controls (from $13{ }^{\circ} \mathrm{C}$ to $29{ }^{\circ} \mathrm{C}$ ) and the location of sensors of wall-mounted thermostats. MNECB also includes provisions for heat pump controls, space temperature controls, and ice and snow-melting heater controls.

(10) MNECB and MNECH require humidistats that can be set down to $30 \%$ relative humidity. 
(11) The HVAC shutoff and setback subsection covers off-hour controls, air flow controls, seasonal shutdown and controls for multiple boilers. MNECH does not have such requirements.

(12) HVAC equipment and components must comply with the relevant federal, provincial or territorial appliance or equipment energy-efficiency acts, or, in the absence of such an act, with the relevant standard as outlined in Table 5.2.13.1, "Heating, Ventilation and Air-Conditioning Equipment Performance Standards." MNECH has similar provisions with less comprehensive coverage.

(13) MNECB specifies the documentation requirements for compliance. MNECH does not have such a subsection.

\section{Prescriptive Requirements $^{22}$}

In MNECB, the prescriptive HVAC system requirements cover (1) fan system design, (2) cooling with outdoor air, (3) control of HVAC systems and $\left(4^{*}\right)$ heat recovery. MNECH only covers heat recovery. The list below summarizes the MNECB prescriptive requirements, and provides a brief comparison to the corresponding subsections in MNECH:

(1) The subsection on fan system design applies to all HVAC fan systems with total power demand of $10 \mathrm{~kW}$ or above. The power demand of a fan system is the sum of the demand of all the fans that supply air to the conditioned space. This subsection also includes specifications for both constant and variable air volume fan systems.

(2) MNECB also contains requirements regarding mechanical cooling systems. The requirements cover systems with air handing capacity of more than 1,500 liters/second or cooling capacity of more than $20 \mathrm{~kW}$. Such systems must use outdoor air to reduce their use of mechanical cooling energy. They can do so with either an air or water economizer system for direct or indirect use of the outdoor air.

(3) A supply air handler must have controls to achieve the supply air temperature without (a) heating previously cooled air, (b) cooling previously heated air or (c) heating outdoor air, separately or mixed with return air (subject to exceptions). This subsection also includes provisions for controlling space temperature by reheating or recooling.

(4) The subsection on heat recovery includes three specific applications. The provisions on heat recovery from dehumidification in swimming pools $\left(4.1^{*}\right)$ state that such systems must be capable of recovering at least $40 \%$ of recoverable heat from exhaust air at the design conditions (with certain exceptions). Given the popularity of ice sports in Canada, another application included is (4.2) heat

\footnotetext{
${ }^{22}$ See Section 5.3 of both MNECB and MNECH.
} 
recovery from ice-making machines in ice arenas and curling rinks. The third application in this section is $\left(4.3^{*}\right)$ heat recovery in dwelling units: the code prescribes performance values for heat-recovery ventilators.

(5) MNECB has a prescriptive requirement for fan energy usage depending on the air handling system. For constant volume air handling systems, the supply fan should not exceed 1.6 watts of power per liter of supply air at design conditions. For variable volume systems, the fan power should not exceed 2.65 watts per liter of supply air at design conditions.

\section{Building Energy Performance Compliance Path ${ }^{23}$}

As an alternative to the prescriptive requirements, building designers can use the building energy performance compliance path. Part 8 outlines the procedures for this option. The designer must demonstrate that the building will not use more energy than it would have if the HVAC system complied with the relevant prescriptive requirements.

MNECB and MNECH have the same provisions for building energy performance compliance.

\subsection{Service Water Heating Systems ${ }^{24}$}

MNECB has both mandatory and prescriptive requirements regarding service water heating systems. MNECH, which applies to water heating systems in a house, only includes mandatory provisions.

\section{Mandatory Requirements ${ }^{25}$}

MNECB requires that "service water heating systems shall be in accordance with provincial, territorial or municipal building regulations, or, in the absence of such regulations, with the National Plumbing Code of Canada 1995." The mandatory requirements of MNECB cover $(1 *)$ storage vessels and heating equipment, $(2 *)$ piping, $\left(3^{* *}\right)$ controls, $\left(4^{*}\right)$ conservation of hot water, and $\left(5^{* *}\right)$ swimming pools. The list below summarizes these and briefly compares them to the MNECH requirements:

(1) MNECB and MNECH do not contain detailed provisions on service water heaters, boilers, storage tanks or pool heaters. They do, however, require that buildings only install equipment that meets the relevant federal or local energy efficiency standards. If there are no such standards for a specific type of equipment, MNECB does provide general performance standards in Table 6.2.2.1, "Service Water Heating Equipment Performance Standards." MNECB requires protected tank insulation with the insulation level dependent on the location of the tank. Service water heating equipment other than hot water storage tanks must be installed in conditioned spaces (MNECB) or inside the building envelope $(\mathrm{MNECH})$.

\footnotetext{
${ }^{23}$ See Section 5.4 of both MNECB and MNECH.

${ }^{24}$ See Part 6 of both MNECB and MNECH.

${ }^{25}$ See Section 6.2 of both MNECB and MNECH.
} 
(2) Piping should be properly insulated. MNECH also has provisions for heat traps.

(3) Service water heating systems with storage tanks must have automatic temperature controls and an accessible device for shutdown (for water heating systems with capacities over 100 liters). MNECH has the same provisions.

(4) The maximum water discharge of individual showerheads is 9.5 liters/minute, and the maximum water discharge of lavatory faucets is 8.3 liters/minute. Each showerhead of a group of shower heads served by one temperature control, and each lavatory in a public access washing room must have an occupancy sensor or self-closing valve. MNECH has no provisions for lavatories, but it does have the same showerhead discharge provisions.

(5) Pool heaters must have a device to shut off the heater without adjusting the thermostat setting. Swimming pools must have a pool cover that can cover at least $90 \%$ of the water. Most pools heated to more than $32^{\circ} \mathrm{C}\left(90^{\circ} \mathrm{F}\right)$ need a pool cover with a minimum insulation value of $0.48 \mathrm{watts} / \mathrm{m}^{2} \cdot{ }^{\circ} \mathrm{C}$. MNECH has almost the same provisions.

\section{Prescriptive Requirements ${ }^{26}$}

In MNECB, the prescriptive requirements for the service water heating systems focus on equipment with multiple functions, including (1) combination service water and space heating equipment, and (2) space heating equipment used for service water heating. MNECH does not have such requirements. The list below summarizes MNECB's prescriptive requirements for service water heating:

(1) Equipment should not be used to provide both space heating and service water heating. This requirement is waived when power input to the combination equipment is less than $45 \mathrm{~kW}$ and the equipment uses less than half the power load needed for equipment that would produce hot water alone.

(2) Space heating equipment used to provide service water heating solely or in combination with space heating must meet the relevant federal, provincial or territorial appliance standard, or, in the absence of such a standard, with the relevant standard in Table 5.2.13.1, "Heating, Ventilation and Air-Conditioning Equipment Performance Standards."

\section{Building Energy Performance Compliance Path ${ }^{27}$}

Building designers have the option of using the building energy performance compliance path instead of meeting the prescriptive hot water heating requirements. Part 8 describes building energy performance compliance.

MNECH does not have this provision, meaning that houses must meet the prescriptive hot water heating requirements.

\footnotetext{
${ }^{26}$ See Section 6.3 of MNECB.

${ }^{27}$ See Section 6.4 of MNECB.
} 


\subsection{Electrical Power ${ }^{28}$}

MNECB and MNECH define electrical systems as those that serve interior and exterior spaces. Emergency systems, on the other hand, need not comply with this part of the code.

Electrical systems must comply with the mandatory provisions of MNECB and MNECH regardless of the compliance path chosen. The mandatory provisions of MNECB include $\left(1^{*}\right)$ electrical distribution systems, $\left(2^{*}\right)$ power controls, (3) transformers, (4) electrical motors and (5) documentation. The list below summarizes these mandatory requirements:

(1) With defined exceptions, dwelling units and suites must have individual metering to ensure billing accuracy. Electrical distribution systems with a load carrying capacity over $250 \mathrm{kVA}$ must have the ability to monitor the energy consumption of each tenant or service with a connected load of $100 \mathrm{kVA}$ or more. MNECB has a subsection on monitoring, while MNECH does not have such a subsection.

(2) Power controls must include switches or timers, with or without manual overrides. The controls must be inside the building. MNECH has similar provisions regarding power controls.

(3) Under MNECB, transformers must comply with the relevant federal or local energy-efficiency standards, or, in the absence of such standards, with good practice. MNECH does not address transformers.

(4) Most electrical motors in buildings must comply with the standards of the Canadian Standards Association. This provision of MNECB does not apply to certain motors, such as elevator motors. MNECH does not address motors.

(5) MNECB specifies the documentation requirements for compliance. MNECH does not address documentation.

In MNECH, the mandatory provisions cover both power distribution systems and power controls. Each house must have an individual meter. The power control provisions in MNECH are similar to those in MNECB.

\subsection{Building Energy Performance Compliance Path ${ }^{29}$}

Performance compliance is an optional alternative to the prescriptive requirements on Building Envelope (2.2), Lighting (2.3), HVAC (2.4), Service Water Heating (2.5) and Electrical Power (2.6) of MNECB and MNECH, and the tradeoff provisions for the Building Envelope (2.2) of both national model codes.

Designers should only use building energy performance compliance when they have sufficient information on a building for a performance analysis. This compliance path cannot be used if a building does not have a mechanical system to provide outdoor air to each conditioned space. Likewise, this compliance path is not an option under MNECB when systems or features that have a significant effect on energy use cannot be analyzed using the compliance software defined in this part (MNECH does not discuss this exception).

\footnotetext{
${ }^{28}$ See Part 7 of both MNECB and MNECH.

${ }^{29}$ See Part 8 of both MNECB and MNECH.
} 


\subsection{Manufactured Housing ${ }^{30}$}

MNECH has a special part on manufactured housing. The code defines this as housing manufactured in a factory and shipped from the factory to its final site in threedimensional form, such as mobile homes. There are certain exemptions to the provisions on building envelopes and HVAC for manufactured housing. For example, manufactured housing that complies with Clause 7 of CAN/CSA-Z240.9.1, "Requirements for Load Calculation and Duct Design for Heating and Cooling of Mobile Home," does not also need to comply with the relevant HVAC provisions of MNECH.

Because this part relates specifically to housing, MNECB does not cover this issue.

\section{Other Developments ${ }^{31}$}

\subsection{R-2000 for New Houses}

The R-2000 Program began in 1981 as a partnership between the Canadian Home Builders' Association and NRCan. The program promotes the use of cost-effective, energy-efficient building practices and technologies. A core part of the program is the R2000 Standard, which demands a high level of energy efficiency, beyond what the building codes require.

NRCan's OEE operates the R-2000 Program. The R-2000 Standard is a voluntary technical performance standard that encourages Canadian builders to build, and consumers to purchase energy-efficient housing. The R-2000 Standard is based on an energy consumption target for each house and a series of technical requirements for ventilation, air tightness (to ensure less drafts), insulation, choice of materials, water use and other factors. ${ }^{32}$

NRCan trains and licenses building professionals in the R-2000 Standard and compatible construction techniques and practices. NRCan also tests and certifies homes for R-2000 compliance. There are now almost 10,000 R-2000 homes, and close to 900 builders with R-2000 licenses.

For more information, please refer to http://oee.nrcan.gc.ca/residential/business/buildersrenovators-trades/r-2000/about.cfm?attr $=12$.

\subsection{EcoENERGY for New Houses}

A system for energy-performance rating and labeling, ecoENERGY for new houses was created to promote the construction and purchase of more energy-efficient houses. Based

\footnotetext{
${ }^{30}$ See Part 9 of both MNECB and MNECH.

${ }^{31}$ Most information in this section is drawn from Office of Energy Efficiency, 2006. Improving Energy Performance in Canada: Report to Parliament under the Energy Efficiency Act For the Fiscal Year 20052006. Natural Resources Canada.

$32 \mathrm{http}$ //oee.nrcan.gc.ca/Publications/statistics/parliament05-06/chapter3.cfm?attr=0.
} 
on the R-2000 Standard and training program, ecoENERGY for Houses is geared towards large-volume, mass-market builders.

EcoENERGY's rating process begins by bringing an energy advisor to evaluate the house plans. The energy advisor will recommend energy-savings upgrades and discuss costeffective options with the client. After the client has approved the costs of the upgrade work and the building has been completed, an ecoENERGY advisor (a third-party contractor) confirms that the recommended upgrades have been incorporated into the house, in addition to performing a blower door test. Once all the tests have been performed, the client receives an ecoENERGY rating label and report.

For more information, please refer to www.oee.nrcan.gc.ca/corporate/eeinitiative.cfm?attr $=0$ and www.ecoaction.gc.ca/ECOENERGY-ECOENERGIE/index-eng.cfm.

\subsection{ECOENERGY for Existing Homes and Incentive Programs}

EcoENERGY Retrofit - Homes offers Canadian homeowners with personalized expert advice on how make their house more energy-efficient. Since October 2003, homeowners can qualify for a non-taxable grant (10 to $20 \%$ of their retrofit expenditures), based on the measures they incorporate in their energy retrofit. In date, March 2009, the program awarded over 194,000 grants totaling \$184 million. The incentive reduced energy consumption by approximately $23 \%$ in post-retrofit homes and reduced greenhouse gas emissions by 3.4 tonnes per house annually (OEE, 2009).

\subsection{EcoENERGY for Existing Buildings}

By offering tools and financial assistance, ecoENERGY for Existing Buildings aids commercial organizations and public institutions in exploring energy efficiency alternatives, which can effectively reduce energy costs and increase competitiveness. After joining this program, members qualify for Energy Retrofit Assistance funding for retrofit planning activities and retrofit implementation projects.

For more information, please refer to http://oee.nrcan.gc.ca/commercial/existing.cfm.

\subsection{Federal Building Initiative}

The Federal Buildings Initiative (FBI) assists departments, agencies and Crown corporations of the Canadian government in adopting energy efficiency upgrades and building retrofits. The initiative provides advice and consultation on project opportunities, model performance contracting documents, public recognition for achievements and a national network for energy management training. The FBI works with federal organizations from a project's inception through contract award, project monitoring and verification.

For more information, please refer to http://oee.nrcan.gc.ca/fbi/home_page.cfm. 


\subsection{Building Energy Simulation Programs}

CanmetENERGY-Ottawa Research Centre develops, distributes and supports building simulation software for the housing and building industry in Canada. CanmetENERGY's software tools help architects and engineers to improve energy performance of individual technologies and whole-building designs, in addition to helping them become eligible for energy-efficient programs such as the R-2000 Standard, ecoENERGY Retrofit - Homes, the Design Validation service.

At the same time, the programs also employ CanmetENERGY's building simulation software. For example, CanmetENERGY developed the HOT2000 ${ }^{\mathrm{TM}}$ computer simulation tool, which is used as the reference calculation program for the R-2000 Program and is also the foundation for the HOT2®XP software used in the ecoENERGY program. More recently, CanmetENERGY's HOT3000 ${ }^{\mathrm{TM}}$ software is expected to be the next generation of Natural Resources Canada's residential energy analysis software. Likewise the EE4 building energy simulation program was developed to support the performance path of the MNECB and prove compliance for code purposes and for programs such as LEED New Construction, utility incentive programs and other purposes. EE4 is an interface for the DOE2.1 building energy simulation engine and an effort is underway to build a new interface based on EQuest building energy simulation software.

For more information, see http://sbc.nrcan.gc.ca/simulation_R_and_D/simulation_R_and_D_e.asp.

\section{Conclusions}

Canada published its first and only model national energy codes, MNECB and MNECH, in 1997. Both model energy codes were heavily influenced by ASHRAE 90.1-1989.

In Canada, building regulation is the responsibility of provincial and territorial governments. To date, very few provinces and cities have referenced MNECB in their building regulations and enforced the corresponding requirements. No province or territory has adopted MNECH in its entirety, although a few have used some of its requirements in their building codes.

Though the existing national model energy codes for buildings and houses have not played central roles in the on-going initiatives for promoting building energy efficiency, the local governments often have their own building energy regulations. Also, the Canadian government has been actively employing other policy instruments, such as:

- Financial incentives (for example, for home retrofits),

- Leadership (such as the Federal Building Initiative),

- Information (for example, the information campaign associated with ecoENERGY),

- Voluntary initiatives (such as the R-2000 program for new houses), and

- Research, development and demonstration (such as the development of HOT3000 ${ }^{\mathrm{TM}}$ ). 
The updated Model National Energy Code for Buildings, which will be released in 2011, is expected to provide Canada's construction sector with a single source of minimum requirements for energy efficiency in buildings.

\section{List of Acronyms}

$\begin{array}{ll}\text { APP } & \text { Asia-Pacific Partnership on Clean Development and Climate } \\ \text { CANMET } & \text { Canada Centre for Mineral and Energy Technology } \\ \text { CCBFC } & \text { Canadian Commission on Building and Fire Codes } \\ \text { CETC } & \text { CANMET Energy Technology Centre } \\ \text { FBI } & \text { Federal Buildings Initiative } \\ \text { GDP } & \text { Gross domestic product } \\ \text { HVAC } & \text { Heating, ventilation and air conditioning } \\ \mathrm{kW} & \text { Kilowatt } \\ \mathrm{m}^{2} & \text { Square meter(s) } \\ \text { MNECB } & \text { Model National Energy Code of Canada for Building } \\ \text { MNECH } & \text { Model National Energy Code for Houses } \\ \text { NRC } & \text { National Research Council } \\ \text { NRCan } & \text { Natural Resources Canada } \\ \text { OECD } & \text { Organisation for Economic Co-operation and Development } \\ \text { OEE } & \text { The Office of Energy Efficiency } \\ \text { R\&D } & \text { Research and development } \\ \text { RSI } & \text { R-value; a measure of thermal resistance in SI units }\end{array}$




\section{References}

1. CCBFC, 1999a. Performance Compliance for Buildings: Specifications for Calculation Procedures for Demonstrating Compliance to the Model National Energy Code for Buildings Using Whole Building Performance. Canadian Commission on Building and Fire Codes.

2. CCBFC, 1999b. Performance Compliance for Houses: Specifications for Calculation Procedures for Demonstrating Compliance to the Model National Energy Code for Buildings Using Whole Building Performance. Canadian Commission on Building and Fire Codes.

3. EIA, 2008. World Carbon Dioxide Emissions from the Consumption and Flaring of Fossil Fuels, www.eia.doe.gov/emeu/international/carbondioxide.html, January 2009, (Accessed).

4. IEA, 2007. Energy Balances of OECD Countries (2007 edition). OECD, Paris.

5. Nationalcodes.ca, 2002. Canada's Code Development System, http://www.nationalcodes.ca/ccbfc/ccds_e.pdf, January 2009, (Accessed).

6. NRC, 2006. Model National Energy Code of Canada for Houses, https://www.nationalcodes.ca/mnech/index_e.shtml, October 2008, (Accessed).

7. NRC, 2007. Model National Energy Code of Canada for Building, https://www.nationalcodes.ca/mnecb/index_e.shtml, October 2008, (Accessed).

8. NRC, 2008. Energy code to get facelift, http://www.nrccnrc.gc.ca/highlights/2008/0804code_e.html, October 2008, (Accessed).

9. OEE, 2006. Improving Energy Performance in Canada: Report to Parliament Under the Energy Efficiency Act For the Fiscal Year 2005-2006. Natural Resources Canada, Ottawa.

10. OEE, 2007. Energy Use Data Handbook Tables (Canada), http://www.oee.nrcan.gc.ca/corporate/statistics/neud/dpa/handbook_tables.cfm?attr=0, October 2008, (Accessed).

11. OEE, 2009. The State of Energy Efficiency in Canada, Office of Energy Efficiency Report 2006. Natural Resources Canada, Ottawa.

\section{Useful Websites}

1. Natural Resources Canada, www.nrcan-rncan.gc.ca/com/index-eng.php

2. The Office of Energy Efficiency, http:/oee.nrcan.gc.ca/english/index.cfm

3. Canada's National Research Council, www.nrc-cnrc.gc.ca/main_e.html

4. Canada's National Code Documents, www.nationalcodes.ca/

5. ecoENERGY, www.ecoaction.gc.ca/ECOENERGY-ECOENERGIE/index-eng.cfm

6. ENERGY STAR, http://oee.nrcan.gc.ca/energystar/english/consumers/index.cfm

7. CanmetENERGY, http://canmetenergy.nrcan.gc.ca/eng/ 



\section{The Asia-Pacific Partnership on Clean Development and Climate}

The Asia-Pacific Partnership on Clean Development and Climate is an innovative new effort to accelerate the development and deployment of clean energy technologies.

\section{Partner Countries}

APP partners Australia, Canada, China, India, Japan, Republic of Korea, and the United States have agreed to work together and with private sector partners to meet goals for energy security, national air pollution reduction, and climate change in ways that promote sustainable economic growth and poverty reduction. The Partnership will focus on expanding investment and trade in cleaner energy technologies, goods and services in key market sectors. The Partners have approved eight public-private sector task forces covering:

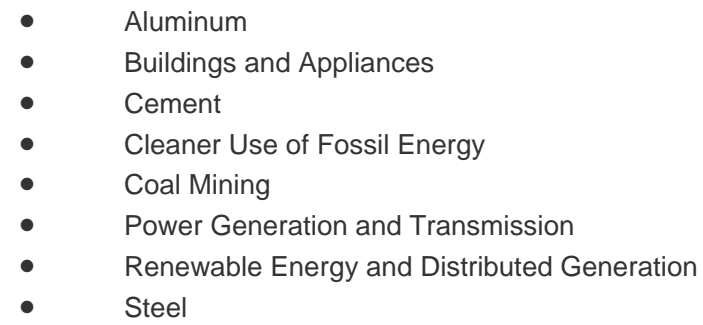

The seven partner countries collectively account for more than half of the world's economy, population and energy use, and they produce about 65 percent of the world's coal, 62 percent of the world's cement, 52 percent of world's aluminum, and more than 60 percent of the world's steel.

\section{Buildings and Appliances Task Force}

Reducing our use of energy for buildings and appliances decreases the demand for primary energy and is a key means to deliver better economic performance, increase energy security and reduce greenhouse gas and air pollutant emissions. Partner countries have recognized for some time the importance of cooperating on energy efficiency for buildings and appliances, and have already taken a range of bilateral and other collaborative actions in this area. As the Partners represent a majority of the world's manufacturing capacity for a diverse range of appliances, we have the potential to drive significant regional and global improvements in energy efficiency in this sector. The Partners will demonstrate technologies, enhance and exchange skills relating to energy efficiency auditing, share experiences and policies on best practices with regard to standards and codes, as well as labeling schemes for buildings, building materials and appliances. 


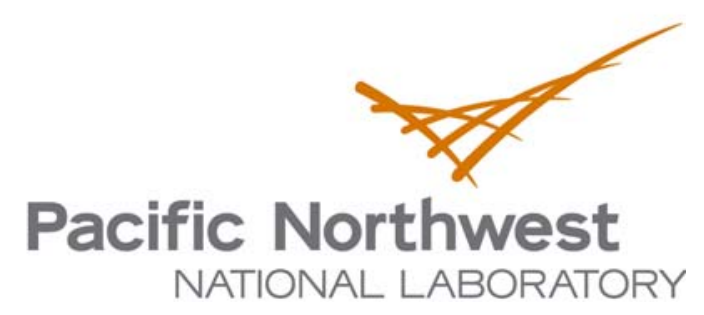

